\title{
Toxic effects of Cleome arabica L. (Capparidaceae) aqueous extracts on mortality and sexual behavior of Drosophila melanogaster (Diptera: Drosophilidae)
}

\author{
Sarra Habbachi - Naziha Amri - Wafa Habbachi iD. Saliha Benhissen - Abdelkrim Tahraoui • Khellaf Rebbas
}

Habbachi S - Amri N • Habbachi W (Corresponding author)

- Benhissen S - Tahraoui A

Laboratory of Applied Neuroendocrinology, Department of Biology, Faculty of Science, Badji Mokhtar University Annaba 23000, Algeria.

email: habbachi.waffa@yahoo.fr

\section{K Rebbas}

Mohamed Boudiaf University of M'sila, Algeria, Laboratory of Agro-Biotechnology and Nutrition in Arid and Semi-Arid Zones, Ibn Khaldoun University, Tiaret, Algeria.

Received: January 02, 2019 - Revised: January 27, 2019 - Accepted: January 28, 2019

\begin{abstract}
Cleome arabica is a spontaneous plant in arid zones, toxic and has hallucinogenic effects. In this work, we seek to evaluate the direct and delayed effect of the aqueous extracts on the vinegar fly Drosophila melanogaster, laboratory model par excellence. Treatment is by ingestion on second instar larvae (L2). The results show that mortality rates can reach $90 \%$ after 15 days of treatment as we recorded a disturbance of fly development. Observation of sexual behavior in treatment-emergent adults indicates that $C$. arabica acts negatively on the course of the different sequences leading to mating in Drosophila.
\end{abstract}

Keywords: courtship, mating, Saharan plant, toxicity, Vinegar fly

\section{Introduction}

Currently, a big effort is doing to control insects-pests by several methods (physical, biological or chemical method). In fact, the global production loss for arthropod pests is estimated at 15\% (Pimentel and Williamson 2008); in addition, post-collect losses in sub-Saharan Africa would be $\$$ 4 billion per year for total annual production estimated at $\$ 27$ billion (2005-2007 annual average) (FAO 2011).

Chemical products used against insects have not been able to completely stop some harmful. In addition, they have increased the environmental record by animals and plants intoxication. The management of these problems has prompted researchers to move towards biological control in its various forms. New methods, as well as new products, are constantly being sought. In addition, to contribute to sustainable environmental management, the introduction of new alternatives for pest control is further encouraged (Louat 2013).
Despite this wide range of effective molecules, the main pests have developed more or less pronounced resistance towards them; this has led to more and more people turning to natural compounds from plants for the development of new insecticidal molecules. The insecticidal activity of aromatic plant extracts has also been confirmed by Jang et al 2002; Habbachi et al 2014; Mahmoudian et al 2002; Habbachi et al 2013; Idrissi-Hassani et al 1998; Abbasi et al 2003; Abbasi et al 2003b; Idrissi-Hassani and Hermas 2008; Abbasipour et al 2010; Masna et al 2016; Benhissen et al 2018).

Plant extracts have been used as insecticides by humans before Romans time, this practice continues to exist with many plants species known for their insecticidal properties (Balandrin et al 1985; Isman 2002). Plant products can be degraded more rapidly in the environment than synthetic compounds, and some may have increased specificity that may favor beneficial insects for the plant (Desneux et al 2007).

The Algerian Sahara has an exceptional floristic biodiversity, consisting of more than 500 species, of which there are 162 endemic species in the northern Sahara alone and to which is added a tradition of traditional pharmacopeia (Ozenda 1991). Several species are known for their remarkable therapeutic properties (Quezel 1978). Spontaneous plants in arid area are considered as phytogenetic resources of agronomic, economic, ecological and strategic interest (UNESCO 1960).

In this work, we search to test direct and indirect toxic effect of the Cleome arabica aqueous extract (Capparidaceae; plant of Algerian Sahara) on the fruit fly Drosophila melanogaster. The work objective is to evaluate the plant effect on mortality, development and sexual behavior of $D$. melanogaster. Drosophila is the best known and most studied in the laboratory among all beings (Tracqui et al 2003). It is 
responsible for the fruits gray mold via the mushrooms that it transports them. Larvae can cause intestinal irritation or diarrhea if swallowed by eating infested fruit.

\section{Materials and Methods}

Insect

Drosophila melanogaster was described by Johann Wihelm Meigen in 1830. Its reproduction is very fast. Its life cycle is very short and includes three larval stages and a pupal stage from which emerges an adult who is able to fly and reproduce.

\section{Mass breeding}

A wild strain recuperated on rotten apples in Annaba region (Algeria) was used. The culture is carried out in tubes $(12 \times 4 \mathrm{~cm})$ clogged with a foam pad and containing a nutrient medium agar based cornmeal and brewer's yeast. The breeding was maintained at $25 \pm 1{ }^{\circ} \mathrm{C}$, a humidity of 70 to $80 \%$ and a scotophase of 12 hours.

\section{Cleome arabica (Capparidaceae)}

It is a toxic plant with foul smell and hallucinogenic effects (Gubb 1913; Ozenda 1991). C. arabica is used in traditional medicine as a diuretic and against rheumatism; it is also a therapeutic and anti-bacterial plant (Ladhari et al 2013).
Species effect has also been proven against different orders of insects (Doumandji-Mitiche and Doumandji 1993; Ozenda 1991; Koïta et al 2012; N'Guessan et al 2009). In this study, the aerial plant parts were collected in the Bousaada region (M'sila, Algeria, N $35^{\circ} 23$ '28 ", E $04^{\circ}$ 18'07", 406 m altitude). The plant was determined by Dr. Khellaf REBBAS (botanist at University of M'sila) using the Algerian flora of Quezel and Santa (1962-1963) (Figure 1).

\section{C. arabica aqueous extract}

For extraction, we put $250 \mathrm{~g}$ fresh leaves in $500 \mathrm{ml}$ of distilled water and boiled for 30 minutes on hotplate $\left(180^{\circ} \mathrm{C}\right)$. The mixture obtained is filtered using filter paper and $250 \mathrm{ml}$ of the filtrate are recovered ( $1 \mathrm{~g} / \mathrm{L}$ stock solution).

\section{Treatment of larvae with C. arabica extract}

We have prepared four different concentrations $35 \mu \mathrm{g} /$ $\mathrm{ml}, 70 \mu \mathrm{g} / \mathrm{ml}, 100 \mu \mathrm{g} / \mathrm{ml}$ and $200 \mu \mathrm{g} / \mathrm{ml}$. The extracts are ingested; each concentration is mixed with $40 \mathrm{~g}$ of food that will be divided into four different tubes. In each tube, 20 second stage larvae are placed. A control tube contain 20 second stage larvae and it doesn't treated by $C$. arabica extracts. The monitoring of mortality and larvae development is done during 15 days (time necessary to finish the development).

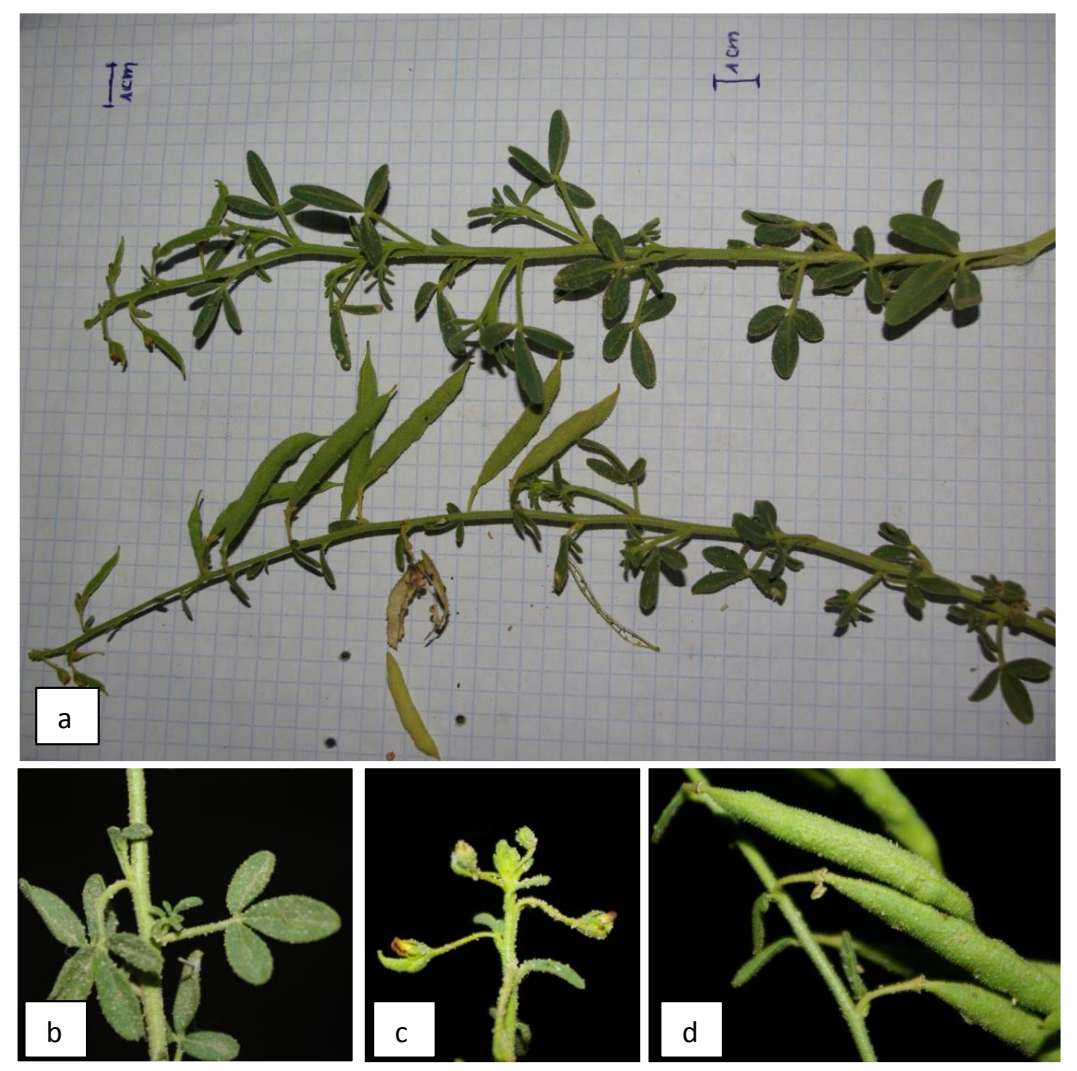

Figure 1 Cleome arabica L. (a. Plante, b. Leaf, c. Flowers, d. Fruit) Bousaada, August 26, 2017, Source: Rebbas K 


\section{Effect of the plant extract on sexual behavior}

Courtship behavior is a succession of predetermined and invariable actions (Clynen et al 2011; Chardonnet 2013). When a male encounters a virgin female, he orients his body in her direction and vibrates alternately each of his wings at a $45^{\circ}$ angle to his main body axis. This vibration is a speciesspecific acoustic signal ('love song'; Bennet-Clark and Ewing 1970; von Schilcher 1976). When she is receptive, the female allows male to lick her genitalia with his proboscis. Then the male attempts copulation by thrusting his genital apparatus in an attempt to grasp the female's genitalia (Lasbleiz et al 2006; Revadi et al 2015).

In this work, we treated larvae with the sublethal concentration of $C$. arabica extract $(35 \mu \mathrm{g} / \mathrm{ml})$ and we recovered adults from their emergence. 48 hours later, these adults will be used for sexual behavioral tests and we note time and contacts number, time and vibrations number, time and licks number, time and attempts number as well as, time and mating duration if is success. These tests are carried out according to four crosses types: control male $\mathrm{X}$ control female, treated male $\mathrm{X}$ treated female, control male $\mathrm{X}$ treated female and treated male $\mathrm{X}$ control female.

\section{Data analysis}

The toxicological parameters (LC50\%, LC90\%, LT50\% and LT90\%) were calculated according to Finney's mathematical methods (Finney 1971). Regarding sexual behavior test, results were analyzed statistically by descriptive metric methods then a variances analysis (ANOVA) was performed on XLSTAT 2009 software (Addinsoft, New York, NY).

\section{Results}

\section{Effect on mortality}

The results show that $C$. arabica aqueous extracts act on larval development time and larval mortality as a function of applied concentration. The concentration $35 \mu \mathrm{g} / \mathrm{ml}$ has a low larvicidal activity. For the three concentrations (70, 100 and $200 \mu \mathrm{g} / \mathrm{ml}), 50 \%$ of the population is killed after 15 treatment days. There is a significant difference between mortality rate recorded for $35 \mu \mathrm{g} / \mathrm{ml}$ concentration $(P=0.02)$, while there is no time effect on mortality for the other concentrations (Table 1).

Table 1 Mortality rate caused by different concentrations of $C$. arabica extracts.

\begin{tabular}{lcccccc}
\hline & $35 \mu \mathrm{g} / \mathrm{ml}$ & $70 \mu \mathrm{g} / \mathrm{ml}$ & $100 \mu \mathrm{g} / \mathrm{ml}$ & $200 \mu \mathrm{g} / \mathrm{ml}$ & Fobs & $P$ \\
\hline 2 days & 1.25 & 1.25 & 2.5 & 1.25 & 0.33 & 0.80 \\
5 days & 2.5 & 1.25 & 2.5 & 1.25 & 0.67 & 0.59 \\
10 days & 2.5 & 11.25 & 20 & 8.75 & 0.11 & 0.95 \\
15 days & 28.75 & 40 & 55 & 50 & 1.53 & 0.26 \\
\hline Fobs & 4.98 & 0.71 & 0.58 & 0.47 & & \\
$P$ & $0.02^{*}$ & 0.56 & 0.64 & 0.71 & & \\
\hline \multicolumn{5}{r}{} & {$\left[(P<0.05)^{*}:\right.$ significant; $(P<0.01)^{* *}$ : highly significant; $(P<0.001)^{* * *}$ : very highly significant $]$} &
\end{tabular}

The larval mortality rates are weakly and positively correlated with extract concentrations used (Table 2A). The $50 \%$ lethal concentration reached $2818.38 \mu \mathrm{g} / \mathrm{ml}$ at 10 days and $131.83 \mu \mathrm{g} / \mathrm{ml}$ at 15 days exposure (Table $2 \mathrm{~A}$ ). $90 \%$ of larvae die with the $5011.87 \mu \mathrm{g} / \mathrm{ml}$ concentration after 15 days (Table 2A).

For lethal times, the results show that there is a strong positive correlation between the mortality rate and the exposure time of larvae to plant extracts (Table 2B). Our results indicate that $\mathrm{LT} 50 \%$ is 81.28 days for low concentrations and 25.70 days for the highest concentration. The LT $90 \%$ reaches 91.20 days for the highest concentration (Table 2B).
Effect on mating success rate

The results show that $C$. arabica aqueous extract administered at a sublethal concentration $(15 \mu \mathrm{g} / \mathrm{ml})$ delete fly mating, regardless of the sex treated in a couple (dyads) (Table 3 ). The mating success rate is $70 \%$ in controls, whereas it reaches $25 \%$ when males are treated with the Saharan plant (Table 3). The aborted mating rate (couples attempting to mate unsuccessfully) and null mating (no attempt or mating) is more important in couples composed by treated males and control females (Table 3).

Effect on the different sequences leading to mating

Effect on the sexual behavior of D. melanogaster 
We recorded that the control and treated couples put, essentially, the same time to establish the first contact between partners. The same result is observed for the different times recorded during the $D$. menlanogaster courtship (first vibration time $P=0.09$, first licking time $P=0.71$, first attempt time $P=0,55$, mating time $P=0.25$, mating duration $P=0.78$ ) (Table 4).
The extract of the $C$. arabica plant has a significant influence on the number of contacts between flies $\left(\mathrm{F}_{\mathrm{obs}}=\right.$ 12.18, $P<0.0001)$, on the number of wing vibrations $(\mathrm{F}=6.64$; $P=0.000)$ and the number of licks $(\mathrm{F}=6.350, P=0.001)$ (Table 4).

Table 2 Mean values of thermographic records of body surface temperature $\left({ }^{\circ} \mathrm{C}\right)$ performed on the left and right sides of the crossbreed cows and calves, according to the times of day.

\begin{tabular}{|c|c|c|c|c|c|c|c|c|c|}
\hline \multicolumn{10}{|c|}{ A } \\
\hline & Right of regression & LC $50 \%$ & LC $90 \%$ & LC84\% & $\mathrm{LC} 16 \%$ & SLOPE & $\int \mathrm{LC} 50 \%$ & $\lim . \operatorname{Inf}$ & $\lim$. Sup \\
\hline 2 days & $\mathrm{Y}=2.71+0.0649(\mathrm{R}=0.16)$ & $1.95 \mathrm{E}+35$ & $1.02 \mathrm{E}+55$ & $3.47 \mathrm{E}+50$ & $1.07 \mathrm{E}+20$ & $1.80 \mathrm{E}+15$ & 230.31 & $8.47 \mathrm{E}+32$ & $1.20 \mathrm{E}+22$ \\
\hline 5 days & $\mathrm{Y}=3.38+0.25 \mathrm{X} \quad(\mathrm{R}=0.55)$ & 3019951.72 & $3.98 \mathrm{E}+11$ & $2.75 \mathrm{E}+10$ & 331.13 & 9113.12 & 4.10 & 735945.29 & 12392372.74 \\
\hline 10 days & $\mathrm{Y}=1.93+0.89 X(\mathrm{R}=0.59)$ & 2818.38 & 77624.71 & 36307.8 & 218.78 & 12.88 & 1.49 & 1897.22 & 4186.80 \\
\hline 15 days & $\mathrm{Y}=3.28+0.81 \mathrm{X}(\mathrm{R}=0.84)$ & 131.83 & 5011.87 & 2238.72 & 7.94 & 16.79 & 1.55 & 85.17 & 204.04 \\
\hline \multicolumn{10}{|c|}{$\mathrm{B}$} \\
\hline & Right of regression & LT $50 \%$ & LT90\% & LT $84 \%$ & $\mathrm{LT} 16 \%$ & SLOPE & $\int \mathrm{LT} 50 \%$ & $\lim . \operatorname{Inf}$ & $\lim$. Sup \\
\hline $35 \mu \mathrm{g} / \mathrm{ml}$ & $\mathrm{Y}=2.11+1.51 \mathrm{X}(\mathrm{R}=0.76)$ & 81.28 & 575.44 & 371.53 & 18.2 & 4.52 & 1.13 & 72.05 & 91.70 \\
\hline $70 \mu \mathrm{g} / \mathrm{ml}$ & $\mathrm{Y}=1.78+2.19 \mathrm{X}(\mathrm{R}=0.88)$ & 29.51 & 112.2 & 83.18 & 10.47 & 2.82 & 1.09 & 27.16 & 32.06 \\
\hline $100 \mu \mathrm{g} / \mathrm{ml}$ & $\mathrm{Y}=1.96+2.36 \mathrm{X}(\mathrm{R}=0.89)$ & 19.5 & 67.61 & 51.29 & 7.41 & 2.63 & 1.08 & 18.05 & 21.07 \\
\hline $200 \mu \mathrm{g} / \mathrm{ml}$ & $\mathrm{Y}=1.68+2.35 \mathrm{X}(\mathrm{R}=0.85)$ & 25.7 & 91.2 & 67.61 & 9.77 & 2.63 & 1.08 & 23.79 & 27.77 \\
\hline
\end{tabular}

\section{Discussion}

Insect control is entering a new botanical phase that provides non - toxic molecules for non - target organisms that are biodegradable and less likely to cause resistance in target species. Medicinal plants have an indefinite source of powerful bio-molecules, pharmacological, cosmetic and food (Duke et al 2008). In this study, we used the aqueous extract of $C$. arabica leaves as a bio-insecticide.

Our results show that $C$. arabica aqueous extracts cause mortality in D. melanogaster larvae. As well as the results of Habbachi et al $(2013 ; 2014)$ and El-Bah et al (2016), in this Drosophila strain, the response to extracts of Algerian spontaneous plants (Peganum harmala and Daphne gnidium) is function of concentration and exposure time of the insects to the plant extract.

C. arabica showed its bioinsecticidal effect against Ectomyelois ceratonin Zeller (Lepidoptera) larvae using aqueous extracts; the effect of $C$. arabica aqueous extract at $15 \%$, starts from the first treatment day, however the impact of this extract at 5\% appears 48 hours later (Korichi Almi et al 2016). Similar work demonstrates C. arabica insecticidal effect on third instar larvae of Spodoptera littoralis (Mediterranean brocade) (N'guessan et al 2009; Ladhari et al 2013).

Several works have highlighted the toxic effect of North African aromatic plants on Diptera such as the Ricinus communis and Tetraclinis articulata effect on larvae of mosquitoes: Culex pipiens (Linnaeus), Aedes caspius (Pallas), Culiseta longiareolata (Aitken) and Anopheles maculipennis (Meigen) (Aouinty et al 2006) and those of Benhissen et al 2018 in Culiseta longiareolata controlled by Nicotiana Glauca. Other studies show that plants in Maghreb arid zones are the most effective even against the most resistant insects such as locusts (Idrissi Hassani and Hermas 2008; Idrissi et al 1998; Idrissi Hassani, 2000; Lebouz 2010; Kemassi and Oueld El-Hadj 2014) or domestic cockroaches (Masna et al 2016). 
Table 3 C. arabica effects $(15 \mu \mathrm{g} / \mathrm{ml})$ on the success rate of $D$. menlanogaster mating.

\begin{tabular}{|c|c|c|c|}
\hline & \multicolumn{3}{|c|}{$\%$ Mating } \\
\hline & Successful & Aborted & Nul \\
\hline $\mathrm{C}^{\lambda} \mathrm{x} \mathrm{C}+$ & $70 \%$ & $20 \%$ & $10 \%$ \\
\hline $\mathrm{C} \delta^{\hat{x}} \mathrm{x} \cdot \mathrm{a}$ 平 & $55 \%$ & $10 \%$ & $35 \%$ \\
\hline 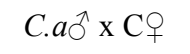 & $25 \%$ & $30 \%$ & $45 \%$ \\
\hline C. $a{ }^{\lambda}$ x C. $a$ 里 & $55 \%$ & $10 \%$ & $35 \%$ \\
\hline
\end{tabular}

C. arabica with their secondary metabolites causes, also, physiological disturbances. Alkaloids dissuade phytophagous insects, affect the nervous system and cell division (Nabors 2008), and have a toxic and paralyzing effect on insects (Regnault-Roger et al 2005).

Plant-based toxicants are one of the most environmentally friendly means of control, some of which are involved in neuroendocrine regulation, metamorphosis, and insect reproduction (Philogene 1991; Rembold 1994). The experience of choosing the male partner was not simply a measure of male preference; Successful copulation also requires the target female to be receptive (Somashekar et al 2011). Males and females sexual behavior is influenced by pheromones. Gr68a gene is expressed in specific neurons of males' anterior legs and is recognized as a pheromone receptor. Inactivation of GR68a gene results in a reduction in male courtship performance (Bray and Amrein 2003). A second candidate, Gr32a, is also involved in phenomenal recognition (Miyamoto and Amrein 2008). Recently, a receptors family has been described ("Flybase PPK" genes family). This family constitutes a new class of pheromone receptors (Thistle et al 2012).

Table 4 Effect of $C$. arabica aqueous extracts on different sequences of D. melanogaster sexual behavior (Mean $\pm \mathrm{SEM}$ ).

\begin{tabular}{|c|c|c|c|c|c|}
\hline & First contact time & First vibration time & First licking time & First attempt time & Mating time \\
\hline $\mathrm{C} \hat{x} \mathrm{x} C q$ & $118,70 \pm 22,88$ & $285,70 \pm 73,59$ & $332,10 \pm 74,08$ & $404,15 \pm 80,70$ & $333,35 \pm 71,35$ \\
\hline C. $a{ }^{\lambda} \mathrm{x} C . a+$ & $80,10 \pm 36,72$ & $190,70 \pm 58,75$ & $262,20 \pm 84,69$ & $370,65 \pm 105,22$ & $324,65 \pm 110,84$ \\
\hline $\mathrm{C} \hat{o} \mathrm{x} C . a$ 우 & $79,85 \pm 35,50$ & $222,95 \pm 54,00$ & $323,40 \pm 79,90$ & $292,00 \pm 80,87$ & $322,15 \pm 96,49$ \\
\hline C. $a^{\lambda} \times \mathrm{C} q$ & $112,95 \pm 61,00$ & $444,60 \pm 186,56$ & $250,55 \pm 80,59$ & $260,75 \pm 99,76$ & $169,50 \pm 97,55$ \\
\hline Fobs & 0,41 & 2,287 & 0,459 & 0,701 & 1,395 \\
\hline \multirow[t]{2}{*}{$P$} & 0,75 & 0,09 & 0,71 & 0,55 & 0,251 \\
\hline & Contacts number & Vibrations number & Licking number & Attempts number & Mating duration \\
\hline $\mathrm{C} \hat{x} \mathrm{x}+q$ & $8,50 \pm 1,14$ & $8,15 \pm 1,83$ & $5,65 \pm 1,33$ & $3,65 \pm 1,09$ & $1179,35 \pm 185,56$ \\
\hline$C . a{ }^{\lambda} \mathrm{x} C . a+$ & $7,20 \pm 7,20$ & $7,45 \pm 2,06$ & $5,95 \pm 1,96$ & $3,15 \pm 1,13$ & $882,15 \pm 208,50$ \\
\hline $\mathrm{C} \widehat{o} \mathrm{x} C . a$ 우 & $11,25 \pm 1,94$ & $11,10 \pm 3,26$ & $5,90 \pm 1,60$ & $2,60 \pm 0,89$ & $905,90 \pm 216,79$ \\
\hline C. $a{ }^{\lambda} \mathrm{x} C q$ & $22,50 \pm 4,48$ & $19,75 \pm 4,72$ & $12,10 \pm 3,11$ & $4,50 \pm 1,92$ & $566,90 \pm 294,78$ \\
\hline $\mathrm{F}_{\mathrm{obs}}$ & 12,18 & 6,64 & 6,35 & 1,98 & 0,361 \\
\hline$P$ & $<0,0001 * * *$ & $0,000 * * *$ & $0,001 * *$ & 0,12 & 0,78 \\
\hline
\end{tabular}

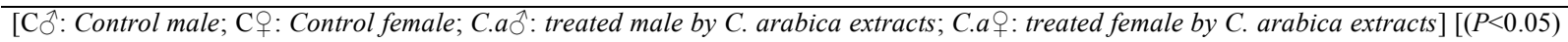

*: significant; $(P<0.01) * *$ : highly significant; $(P<0.001) * * *$ : very highly significant $]$ 
In the present study, we noticed a disruption of different coupling sequences in D. melanogaster adults by the indirect effect of $C$. arabica aqueous extract. It was demonstrated that flies don't mate when couple is formed by treated males and control females, after some contact between partners, no courtship is observed this may be a change in the cuticular profile in flies. Contacts role in the partners mutual recognition has been proven in different insects species such as cockroaches (Roth and Willis 1952; Farine et al 1993; Gropeaux, 1994). In the goal of bioactive molecules research powerful against vinegar fly, Spinosad, Bacillus thuringiensis var kurstaki, Azadiractine, and P. harmala are bioinsecticides that have proven their activity on mortality and sexual behavior of D. melanogaster (Bensafi 2010; Bourbia 2012; ElBah et al 2016). In this study, we show that control couples take longer than in treated couples; the study shows, also, that the aromatic plant extract acts (C. arabica) on key sequences leading to mating (vibration, licking and mating attempts).

\section{Conclusions}

This study indicates that $C$. arabica aqueous extract has a neurotoxic property, the sublethal concentration of the extract $15 \mu \mathrm{g} / \mathrm{ml}$ shows that treated individuals are incapable of presenting a complete sexual behaviour. A chemical analysis of treated and control flies can provide information on any changes in adult D. melanogaster courtship, pheromone secretions, mating time, and various males sexual behavior sequences. This work results suggest the presence of toxic substances in the studied extract which can lead to developing bioinsecticides based on $C$. arabica and which will be used in agriculture and sold on pesticide market.

\section{References}

Abbassi K, Mergaoui L, Atay-Kadiri Z, Stambouli A, Ghaout S (2003a) Effets des extraits de Peganum harmala (Zygophyllaceae) sur le criquet pèlerin (Schistocerca gregaria, Forskål, 1775). Zoologica Baetica 14:203-217.

Abbassi K, Atay-Kadiri Z, Ghaout S (2003b) Biological effects of alkaloids extracted from three plants of Moroccan arid areas on the desert locust. Physio. Entomo 28:32-236.

Abbasipour H, Mahmoudvand M, Rastegar F, Basij M (2010) Insecticidal activity of Peganum harmala seed extract against the diamondback moth, Plutella xylostella. Bull. Insect 63:259-263.

Aouinty B, Oufara S, Mellouki F, Mahari S (2006) Évaluation préliminaire de l'activité larvicide des extraits aqueux des feuilles du ricin (Ricinus communis L.) et du bois de thuya (Tetraclinis articulata (Vahl) Mast.) sur les larves de quatre moustiques culicidés : Culex pipiens (Linné), Aedes caspius (Pallas), Culiseta longiareolata (Aitken) et Anopheles maculipennis (Meigen). Biotechnol Agron Soc Environ 10:67-71.

Balandrin MF, Klocke JA, Wurtele ES, Bollinger WH (1985) Natural plant chemicals: Sources of industrial and medicinal materials. Science 228:1154-60.
Benhissen S, Rebbas K, Habbachi W, Masna F (2018) Bioactivity of Nicotiana glauca Graham (Solanaceae) and its toxic effects on Culiseta longiareolata (Diptera; Culicidae). Inter J Res Ayur Pharm 9:123-126.

Bensafi H (2010). Etude ecophysiologique, systématique et lutte intégrée contre les drosophiles, vecteurs de la pourriture grise dans les cultures. Magister thesis, University of Annaba (Algeria). 67p.

Bourbia S (2012) Étude de la souche sauvage de Drosophila melanogaster agent de la pourriture grise des fruits. Identification et Comportement sexuel. Magister thesis, University of Annaba (Algeria). 80p.

Bray S, Amrein H (2003) A putative Drosophila pheromone receptor expressed in male-specific taste neurons is required for efficient courtship. Neuron 39:1019-1029.

Chardonnet $\mathrm{F}$ (2013) Rôle du gène foraging dans l'évolution du comportement alimentaire de noctuelles foreuses de céréales. Doctorate thesis. University of Pierre et Marie Curie, Gif-sur-Yvette (France). 245p.

Clynen E, Ciudad L, Bellés X, Piulachs MD (2011) Conservation of fruitless' role as master regulator of male courtship behaviour from cockroaches to flies. Dev Genes Evol 221:43-48.

Desneux N, Decourtye A, Delpuech JM (2007) The sublethal effects of pesticides onbeneficial arthropods. Annu. Rev Entomol 52:81106.

Doumandji-Mitiche B, Doumandji S (1993) Essai de lutte biologique contre la Pyrale des Caroubes Ectomyelois ceratoniae Zeller (Lep., Pyralidae) par utilisation de Trichogramma embryophagum (Hym., Trichogrammafidae) à Ouargla. Rapport de synthèse de l'atelier "Lutte biologique dans les oasis ".Ed. CIHEM Montpellier, Mediterranean Options: Mediterranean Seminars. 183.

Duke AJ, Duke PAK, Ducellie JL (2008) Duke's Handbook of medicinal plants of the Bible. Ed. CRC. Press, 552p.

El-Bah D, Habbachi W, Ouakid ML, Tahraoui A (2016) Sublethal effects of Peganum harmala (Zygophyllaceae) on sexual behavior and oviposition in fruit fly Drosophila melanogaster (Diptera: Drosophilidae). J Entomo Zoo Stud 4:638-642.

FAO (2011) The State of Food and Agriculture. Food and Agriculture Organization of the United Nations Rome. 160p.

Farine JP, Le Quéré JL, Duffy J, Sémon E, Brossut R (1993) 4Hydroxy 5-methyl-3-(2H)-furanone and 4-hydroxy-2, 5-dimethyl- 3$(2 \mathrm{H})$-furanone, two components of the male sex pheromone of Eurycotis floridana (Blattidae). Biosci Biotech Biochem 57:20262030.

Finney DJ (1971) Probits analysis. $3^{\text {rd }}$.ed., Cambridge University Press. London.

Gropeaux JC (1994) Comportement sexuel de Diploptera punctata (Dictyoptera, Blaberidae): Approche éthologique. Diploma of Advanced Studies in Biology. Paris XIII University (France). 18p.

Gubb AS (1913) La flore saharienne: un aperçu photographique. Ed. Adolphe Jourdane, Algiers, 129p.

Habbachi W, Benhissen S, Ouakid ML, Farine JP (2013) Effets biologiques d'extraits aqueux de Peganum harmala (1.) (Zygophyllaceae) sur la mortalité et le développement larvaire de Drosophila melanogaster (Diptera - Drosophilidae). Alg J Arid Env 3:82-88.

Habbachi W, Benhissen S, Ouakid ML, Farine JP, Bairi A (2014) Toxicity of aqueous extracts from Mediterranean plants on Culex 
pipiens (Mosquitoes).Case of Daphne gnidium (Thymelaeaceae) and Peganum harmala (Zygophyllaceae). Wulf 21:244-252.

Idrissi Hassani LM (2000) Contribution à l'étude phytochimique du harmel Peganum harmala L. (Zygophyllaceae) et étude de ses effets sur la reproduction et le développement du criquet pèlerin Schistocerca gregaria Forsk. Doctoral thesis, University of Ibn Zohr, Agadir (Morocco). 214p.

Idrissi Hassani LM, Hermas J (2008) Effets de l'alimentation en Peganum harmala L. (Zygophyllaceae) sur le tube digestif du criquet pèlerin Schistocerca gregaria Forsk. (Orthoptera, Acrididae). Zool Baetica 19:71-84.

Idrissi Hassani LM, Ould Ahmedou ML, Chihrane J, Bouaichi A (1998) Effets d'une alimentation en Peganum harmala (Zygophyllaceae) sur la survie et le développement ovarien du criquet pèlerin Schistocerca gregaria Forskål (Orthoptera, Acrididae). Ethnopharmacologia 23:26-41.

Isman MB (2002) Problèmes et perspectives de commercialisation des insecticides d'origine botanique in Regnault-Roger C., Philogène B.J. and Vincen C., 2002. Biopesticides d'origine végétale. Ed. Tec and Doc, Lavoisier, Paris, 301-311p.

Jang YS, Baek BR, Yang YC, Kim MK, Lee HS (2002a) Larvicidal activity of leguminous seeds and grains against Aedes aegypti and Culex pipiens pallens. J Am Mosq Control Assoc 18:210-213.

Kemassi A, Bouziane N, Boual Z, Ould El Hadj MD (2014) Activité biologique des huiles essentielles de Peganum harmala L. (Zygophyllaceae) et de Cleome arabica L. (Capparidaceae) sur Schistocerca gregaria (Forskål, 1775). Phytotérapie 12:348-353.

Koïta K, Neya FB, Nana AT, Sankara P, Biosci JA (2012) Activité antifongique d'extraits de plantes locales contre Puccinia arachidis Speg. J App Biosci 57:4142-4150.

Korichi-Almi A, Bissati-Bouafia S, Bensalah K, Korichi R (2016) Effets de l'extrait aqueux de Cleome arabica sur les larves de premier stade d'Ectomyelois ceratoniae Zeller (Lepidoptera, Pyralidae). Rev Bio Ress 6:62-69.

Ladhari A, Laarif A, Omezzine F, Haouala R (2013) Effect of the extracts of the spiderflower, Cleome arabica, on feeding and survival of larvae of the cotton leafworm, Spodoptera littoralis. J Insect Sci DOI: $10.1673 / 031.013 .6101$

Lasbleiz C, Ferveur JF, Everaerts C (2006) Courtship behaviour of Drosophila melanogaster revisited. Ani Behav 72:1001-1012.

Lebouz I (2010) Activité biologique des extraits foliaires de Cleome arabica L. (Capparidaceae) chez Schistocerca gregaria (Forskål, 1775) (Orthoptera, Acrididae). Magister thesis, University of Biskra (Algeria). 165p.

Louat F (2013) Etude des effets liés à l'exposition aux insecticides chez un insecte modèle, Drosophila melanogaster. Doctoral thesis. Orleans University (France). 224p.

Mahmoudian M, Jalilpour H, Salehian P (2002) Toxicity of Peganum harmala, Review and a Case Report. Iran J Pharm Therap 1:1-4.
Masna F (2016) Inventaire de la faune Blattoptère urbaine et forestière dans la région aride de Laghouat. Caractérisation des principales espèces nuisibles et essais de lutte. Doctoral thesis. University of Annaba (Algeria). 153p.

Miyamoto T, Amrein H (2008) Suppression of male courtship by a Drosophila pherpmone receptor. Nat neurosic 11:874-876.

N'guessan K, Kadja B, Zirihi GN, Traoré D, Aké-Assi L (2009) Screening phytochimique de quelques plantes médicinales ivoiriennes utilisées en pays Krobou (Agboville, Côte-d"'Ivoire). Sci and Nat 6:1-15.

Nabors M (2008) Biologie végétale (structure, fonctionnement, écologie et biotechnologie). Ed, Nouveaux horizons, Paris, 614p.

Ozenda P (1991) Flore de Sahara. Mise à jour et augmentée. Third Edition Dunod, CNRS, Paris, 662p.

Philogène BJR (1991) L'utilisation des produits naturels dans la lutte contre les insectes: problèmes et perspectives. La lutte antiacridienne. Ed. AUPELF-UREF, John Libbey Eurotext, Paris, 269278p.

Pimentel D, Williamson S (2008) Reducing Energy Inputs in the US Food System. Springer Science. Business Media, LLC. DOI 10.1007/s10745-008-9184-3.

Quezel P, Santa S (1962-1963) Nouvelle flore de l'Algérie et des régions désertiques méridionales. CNRS, Ed, Paris, v.2, 1170p.

Quezel P (1978) Peuplement végétal des hautes montagnes de l'Afrique du nord. Encyclopédie biogéographique et écologique. Ed, Paul Lechevalier, Paris, 463p.

Regnault-Roger C, Fabres G, Philogene B (2005) Enjeux phytosanitaires pour l'agriculture et l'environnement. Ed, Lavoisier Tec et Doc, Paris, 749p.

Rembold H (1994) Controlling locusts with plant chemicals. New Trends in Locust Control (eds. S. Krall, H. Wilps), GTZ, Eschborn, TZ-Verlagsgesellschaft Rossdorf, 41-49.

Revadi S, Lebreton S, Witzgall P, Anfora G, Dekker T, Becher PG (2015) Sexual Behavior of Drosophila suzukii. Insects 6:183-196.

Roth LM, Willis R (1952) A study of cockroach behaviour. Am Midl Nat 47:66-129.

Somashekar K, Krishna MS, Hegde SN, Jayaramu SC (2011) Effects of age on female reproductive success in Drosophila bipectinata. J Insect Sc. 11:1536-2442.

Thistle R, Cameron P, Ghorayshi A, Dennison L, Scott K (2012) Contact Chemoreceptors Mediate Male-Male Repulsion and MaleFemale Attraction during Drosophila. Cell 149:1140-1151.

Tracqui P, Demongeot J (2003) Eléments de biologie à l'usage d'autres disciplines de la structure aux fonctions: De la structure aux fonctions. EDP Sciences Editions, 94-95.

UNESCO (1960) "Les plantes médicinales des régions arides. Recherches sur les zones arides", Paris, 99p. 